\title{
Evaluating the Implementation of Policy on Education Board
}

\author{
Endang Sri Budi Herawati1 ${ }^{*}$, Suryadi ${ }^{1}$, and Bejdo Sujanto1 \\ 1Department of Education Management, Universitas Negeri Jakarta, Jakarta Timur, 13220, Indonesia \\ endang.sri.budi.herawati@mahasiswa.unj.ac.id; hcsuryadi.unj@gmail.com; bejosujanto@unj.ac.id; \\ ${ }^{*}$ Corresponding Author
}

How to Cite : Herawati, E., S., B. Suryadi, S., Sujanto, B., (2019). Evaluating the Implementation of Policy on Education Board. International Journal for Educational and Vocational Studies, 1 (3), 236-243.

\section{ARTICLE HISTORY}

Received: 8 May 2019

Revised: 21 May2019

Accepted: 22 July 2019

\section{KEYWORDS}

Board of Education; society participation; Discrepancy Evaluation Model,

\begin{abstract}
This study was designed to discuss government policies on the Board Education, so conclusions can be obtained about these policies for the sake of improving the quality of education services. This study uses evaluation with a discrepancy evaluation model (DEM) consisting of four works: design, installation, process, and product. The data were collected through a combination of observation techniques, document studies, interviews, and questionnaires, with qualitative data analysis. The data sources in this study were the Education Board, the Education Office, DPRD, BAPPEDA, and several school principals who were deliberately chosen to collect research data. The results showed that unclear rules regarding funding sources for the Board Education was the main obstacle in the implementation of the work program. At the design and installation stage, there are no gaps, and policies have been applied by reference to existing rules. However, at the process and product stages, there are gaps where only a small number of programs have been prepared. This also results in a gap at the product stage, which results in the goal of forming an Education Board not being achieved. Work programs as operational roles and functions of the Board Education have been arranged according to the purpose of its formation. but limited budget and human resources were obstacles to optimizing the contribution of Board Education to improving the quality of education services. Full support from the government and regional government related to the allocation of funds for the operation of the Board Education, both through the allocation of APBD and through the Regulations of the Regent related to managing the allocation of Corporate Social Responsibility (CSR) activities from various companies in Cirebon District, so that improving the quality of education services can be more equitable, and the role of DUDI in developing education can be felt evenly throughout the Cirebon district. The Education Agency's readiness is needed to accept the presence of the Education Council as a strategic partner in the development of Education, and the need for delegation of authority related to the development and empowerment of the School Committee by the Education Board.
\end{abstract}

This is an open access article under the CC-BY-SA license.

\section{INTRODUCTION}

The Education Board is a manifestation of community participation in decision making in the education sector to improve the quality of education services as mentioned in national education system law No. 20 of 2003. The Education Board as an independent institution is formed and plays a role in improving the quality of education services by providing consideration, direction, and support of personnel, facilities and infrastructure, as well as education supervision at national, provincial and district/city levels that do not have any hierarchical relationship with other government institutions (Depdiknas, 2002) (Pemerintah Republik Indonesia, 2010). The Education Board formed through Kepmendiknas No. 044/U/2002, in some regions the performance was discussed. The Education Board is referred to as a "stamp institution" which legalizes deviant practices that dama- ge education (Pikiran Rakyat, 2015). Raihan Iskandari, a member of Commission X DPR concludes that Kepmendiknas No. 044/U/2002 opens opportunities for levies by the School Committee stated that one of the functions of the School Committee is to raise public funds in the context of financing education in educational units (Kompas.com, 2012). This is the negative perception of the existence of the Education Board and School Committee as an institution that accommodates community participation.

However, several studies provide information that public perceptions of the Board of Education institutions are quite good, and are considered necessary as a forum for the community to participate in improving the quality of education, and have contributed to improving the quality of education (Iwan Panji, 2018) (Evaluation Study 
on the Impact of the Education Board/School Committee's Contribution to the Improvement of Secondary Education Quality, 2011) (Hendarman, 2012). It's just that in the implementation of their roles and functions, constructive synergy and communication are needed and clear partnership rules between the education council, the education office, school committees, principals and teachers (Suryono, Santosa, \& Haryadi, 2013). The government should revise government regulations that prohibit the partitioning of society, given the increase in school autonomy and empowering community participation will also be able to realize the achievement of better school-based management as an effort towards better education (Santoso \& Zulaikha, 2017). The concept of community participation is very important throughout the world. In developed countries the community has an important role in the process of planning and developing education, but in third world countries there are several important obstacles in facing community participation in education activities (Aref, 2019). Community participation in education can be in the form of: 1) financial support; 2) ideas; 3) non-material/support, which is managed through participatory management (Wiratno, 2016). Even though community participation is not a panacea to overcome the problem of Education, but the involvement of the community in the Education program facilitates the process of identifying Education problems and formulates effective strategies to overcome these problems by mobilizing existing Education resources in the community (Pailwar, Mahajan, \& Africa, 2005). There are a number of things that have caused Indonesian people's participation in education to be still low, among others: (1) social, cultural, geographical conditions of the Indonesian people, (2) financial helplessness of the community in terms of financing, and (3) policy making that does not take into account (Mas, 2011).

The Cirebon District Government has pioneered the formation of the Education Board and empowered School Committees at the education unit level. This was done in order to develop community concrete alignments with regard to the implementation of quality education, while at the same time implementing Kepmendiknas No. 044/U/2002. To date, the Cirebon District Education Board has experienced management changes of four periods of leadership, since its inception in 2002. However, the fact about the development of education in Cirebon Regency is still not satisfactory. Every year, Cirebon Regency still leaves five percent of elementary school graduates who do not continue to junior high school level, and this could be an indication of the success of the nine-year compulsory education program ("Education Blur Portrait of Cirebon Regency,Cirebon News online," 2016). The primary school dropout rate in Cirebon District in 2017 is 2.26 Government Agency Performance Accountability Report (LAKIP) Cirebon District Education Office, 2018). This figure is relatively high because the School Dropout Rate (APS) should not exceed 1\% of the number of students attending school (Decree of the
Minister of National Education of the Republic of Indonesia Number 129a/U/2004 concerning Minimum Service Standards in the Field of Education, 2004). The achievement of Cirebon Regency Education Indicators 2013 - 2017 is presented in the following figure.

\begin{tabular}{|c|c|c|c|c|c|}
\hline & 1 & 2 & 3 & 4 & 5 \\
\hline Education Index & 77,9 & 80,04 & 81,9 & 82,93 & 84,27 \\
\hline - Literacy Numbers & 93,52 & 93,89 & 94,26 & 94,63 & 95 \\
\hline $\begin{array}{l}\text { Average length of } \\
\text { school }\end{array}$ & 6,89 & 7,01 & 7,4 & 7,5 & 7,9 \\
\hline - Hope in Old School & 11,48 & 11,6 & 11,79 & 12,03 & 12,21 \\
\hline
\end{tabular}

Figure 1. Educational Indicators Achievement 2013-2017

Source: (Government Agency Performance Accountability Report (LAKIP) Cirebon District Education Office, 2018)

Figure 1 shows that the education index in Cirebon Regency is relatively stagnant. There is a gap between Average Length of School (RLS) and Expectation of School Length (HLS). In 2017 the average length of school (RLS) was 7.9 with a School Length of Hope (HLS) of 12,21. This number means that the people of Cirebon have hopes of completing high school, but in fact they have just graduated from elementary school or dropped out in grade 2 of junior high school. This figure is an indication that the 9-year basic education program is unfinished. Various facts about the Education Board and the achievements of the development of the education sector have become an interesting study. It is understandable that the strategic role of the Education Board in improving the quality of education is the goal of establishing this institution. But various perceptions of the existence of this institution are also noteworthy. Therefore, it is necessary to conduct an evaluation study of the implementation of the policies underlying the formation of the Education Board. This is done to understand whether this institution has really carried out its role and function in guarding the management and implementation of education, has a critical power in making education policy in the region, so that the quality of education services is getting better.

\section{METHODS}

This research is a policy evaluation study using a gap evaluation model (DEM) consisting of 5 stages, namely:(1) the design phase; (2) installation phase; (3) the process stage; (4) results stage; and (5) the comparison stage. Provus said that if only one policy was evaluated, the fifth stage was not necessary because this stage was the stage of comparing the cost benefits of each program evaluated (Provus, 1969). Therefore, the evaluation model in this 
study is the DEM (Discrepancy Evaluation Model) with four stages that have been modified according to the purpose of the research, namely the design phase I, stage II Installation, stage III Process, and stage IV Product. The step description used includes analyzing the data and determining the level of output obtained from the measurement activity and checking the level of achievement of the objectives according to the standard. The next stage compares the results achieved with the goals set. The concept of DEM in this study can be seen in the following figure 2 .

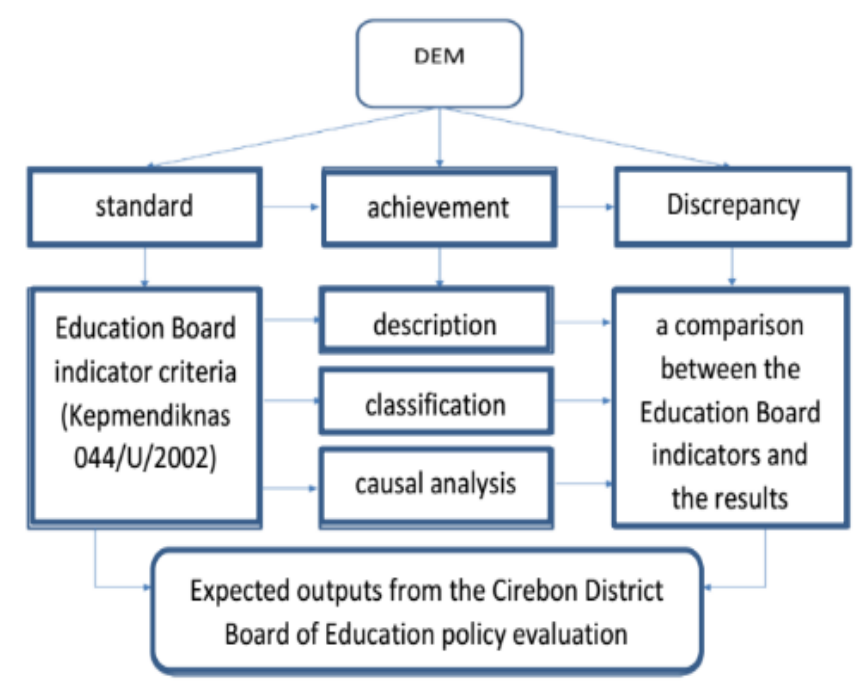

Figure 2. DEM Evaluation Concept
Based on the figure 2 it can be explained that at the design stage, evaluation is carried out to see how the basis of policy, the purpose of formation, the reference to the formation, role and function of the Education Board, organization and the arrangement of relations between organizations as stipulated in Kepmendiknas No. 44/U/2002 applied and underlies the policy of the Cirebon Regent in forming the Education Board (which is stated in the Regent's Decree). At the installation stage, evaluation is carried out to see whether there are gaps that occur when the Education Board that has been formed, develops a vision/mission, work guidelines, work mechanism, and work program using the provisions contained in the Regent Decree as its legal basis. Furthermore, at the process stage, evaluation is carried out to see the implementation of the program in accordance with the objectives to be achieved and the planned implementation time, as well as the implementation of the roles and functions carried out by the Education Board. At the product stage, an evaluation was carried out to see whether there were any gaps between the objectives of the establishment mandated by Kepmendiknas No. 44/U/2002 with the facts/conditions that occurred in Cirebon Regency. The research subjects consisted of the chairperson and secretary of the Education Board, Education Office, Cirebon Regency DPRD, business field (DUDI), and several publicschool principals in Cirebon District who were sampled purposively. Methods of collecting data using observation, in-depth interviews, questionnaires and documentation studies. Data source triangulation is used to test the validity of data, while data analysis techniques use inductive analysis techniques.

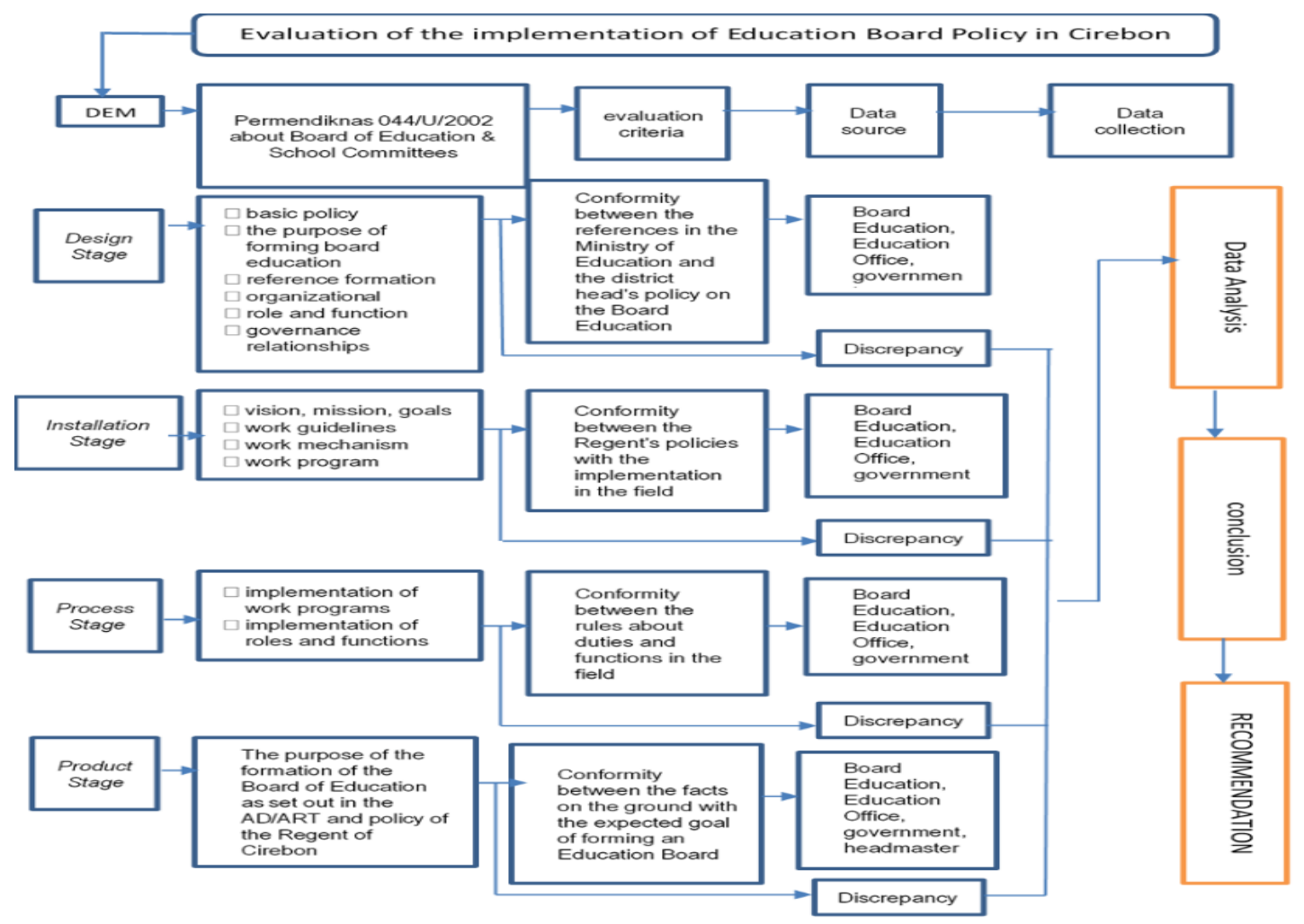

Figure 3. Design of Evaluation Framework 



\section{RESULTS AND DISCUSSION}

\section{Design Stag}

Aspects evaluated at the design stage are: (1) Basic Policy; (2) Formation Objectives; (3) Reference to Formation, (4) Roles and Functions of the Education Council; (5) Organization of the Education Council; and (6) Governance of Inter-Organizational Relations. The evaluation results at this stage indicate that the policy on the formation of the Education Board has a legal basis in accordance with regulations (laws, government regulations, and other related regulations) that have been previously set. The foundation of policy law is an important factor that supports the success of policy implementation. The existence of a legal foundation in accordance with regulations can be seen as political legitimacy in supporting policy implementation. Policies that are free from regulatory contradictions will be easier to implement than policies that experience opposition to other regulations.

The Education Board was formed to accommodate community participation as mandated by Kepmendiknas No. 044/U/2002 which forms the basis of the policy for the formation of the Education Board. Educational Board Institutions were also formed in other countries including Japan, America and South Korea. This institution has more or less the same function of contributing to various Education policies (Muhtadi, 2008). Another rule that forms the basis of the policy for establishing the Education Board is national education system law No. 20 of 2003 concerning the National Education System article 56 paragraph 1 and 2, namely: (a) Article 56 (1) the community plays a role in improving the quality of education services which include planning, supervision and evaluation of educational programs through the Education Board and School/madrasah Committee; (b) Article 56 (2) The Education Board as an independent institution is formed and plays a role in improving the quality of education services by giving consideration, direction and support of personnel, facilities and infrastructure, and supervision of education at the National, Provincial and Regency/City levels that do not have hierarchical relationship (National Education System Law, 2003). From this it can be concluded that the Education Board was formed to take a role in improving the quality of education services. Independence, which is prioritized in organizational and relationship management between organizations, has advantages and disadvantages. The advantage is that as an independent institution the Education Board can arrange work programs according to the needs and input of the community, and not merely adjust the program of the Regional Government or even the Office of Education. While the weakness that might arise is the budget constraint considering there is no budget allocation from the Regional Government to the Education Council, except through grant funds. In addition, because there are no hierarchical pathways with schools or other government agencies, it is not easy for the Board of Education to communicate and coordinate work. In the implementation level, implementing policies is a key factor that needs to be considered before the policy is implemented. Every element involved must understand well the goals and objectives of the policy that will be applied. This understanding will direct the executor's actions in carrying out each stage of the activity process in implementing the policy. Implementers will be able to implement policies well if they have a good understanding of policy goals and objectives. The way the implementer applies the policy depends on the extent of understanding the policy objectives.

\section{Installation Stage}

Evaluation at this stage was carried out on 4 aspects, namely: (1) Vision, mission and objectives; (2) work guidelines; (3) work mechanism; and (4) work program. The evaluation results show that all aspects of the installation phase have been carried out according to the provisions stipulated in the Decree of the Regent No. 420/Kep.539 - Disdik/2015 which is the legal basis for the Education Board in carrying out its duties. After being confirmed, the Education Board has evaluated its $A D / A R T$, and this means that a review of the vision and mission has been carried out in accordance with the vision and mission of the Regional Government and the Cirebon District Education Office. The revision of the $A D / A R T$ as a working guideline of the Education Board has also referred to the organizational rules and procedures for working relations stipulated in Kepmendiknas No. 044/U/2002 and stated in the Decree of the Regent, and Government regulations No. 17 of 2010 concerning Management and Implementation of Education.

In its implementation, at the beginning of the management period, the Education Board always reviews $A D / A R T$, adapting to the latest rules that exist because $A D / A R T$ is a working guideline for the Education Board. Work guidelines are written standards/guidelines that are used to encourage and mobilize all members of the Cirebon Regency Education Board to achieve organizational goals. This work guideline clarifies the task, authority and responsibility of each member of the Education Board. All activities of the Education Board refer to the applicable laws and regulations and $A D / A R T$.

It is understandable that in carrying out their duties, roles and functions, the Education Board has developed a working mechanism. The work mechanism that has been compiled in addition to regulating the flow of the main tasks and functions implementation, also shows the independence of the Education Board which is indeed mentioned as an independent institution and does not have a hierarchical relationship with local government institutions. Its coordinative working relationship built with related institutions is coordinative. This is in accordance with the rules stipulated by the Bupati Decree stating that the Education Boad is an independent 
institution. In the $A D / A R T$ a clause has also been stipulated stating that the Education Board is an independent institution that is independent and non-profit, and includes non-structural institutions.

The Education Board is a manifestation of community participation in improving the quality of education services. Therefore, the work program is structured as a form of the Education Council's efforts in carrying out its roles and functions. The work program is in line with the description in Cirebon Regency Regional Regulation number 13 of 2011 concerning the Implementation of Education, Chapter XIII article 37 which states that community participation in education is as follows: (1) the community can participate as implementing resources and users of educational outcomes and the control function of implementing education; (2) the community as intended includes individuals, groups, families, professional organizations, entrepreneurs and community organizations (Pemerintah Daerah Kabupaten Cirebon, 2011). Furthermore, Article 38 mentions that the District Education Council as an independent institution is formed and plays a role in improving the quality of education services by giving consideration, direction, support of personnel, facilities, infrastructure, mediators and supervision of the implementation of education at the district level that has no hierarchical relationship (Pemerintah Daerah Kabupaten Cirebon, 2011). For this reason, the work program was prepared by the Education Board, so that it can carry out its roles and functions properly according to the needs of the community.

\section{Process Stage}

Delegation of authority in the field of Education to the City/Regency government, raises the concept of Education management which gives flexibility to schools to regulate and implement various policies widely, through the concept of School Based Management (Caldwell, 2005), (Yau \& Cheng, 2011), (Cheng, 1996), (Ehren, Honingh,
Hooge, \& O'Hara, 2013). For this reason, the Education Board was formed, as a forum for community participation in Education (Hooge \& Honingh, 2014), (Suru, 2013), (Pardji, 2011), (Coles, Daniel, \& Naveen, 2012), (Johnson, 2012). The Cirebon Regency Education Board has not been optimal in carrying out its activities. Many work programs have not been implemented due to budget constraints and human resouces. Most of the programs carried out were the Department of Education program which included the Education Board in the implementation of the monitoring and evaluation program, namely: (1) $P P D B$ program; (2) BOS program; and (3) $U N / U A S B N$ program. The role and function of the Education Board are internalized in the operational activities carried out by the Education Board in accordance with their roles and functions (National Education System Law, 2003). The implementation of the roles and functions of the Board of Education that are internalized in operational activities can be seen in the following tables (source: adapted from the Operational Reference \& Performance Indicators of the Education Board, Education Board Development Team, Ministry of National Education, October 2003 (Ministry of National Education, 2003) adjusted to the conditions happened in the Cirebon District Board of Education.

\section{Advisory Agency}

\section{Function}

Provide input, consideration and recommendations to the regional government/DPRD regarding: (1) education policies and programs; (2) regional performance criteria in the field of education; (3) criteria for education staff, especially teachers/tutors and heads of education units; (4) criteria for educational facilities; and (5) other matters related to Education.

Table 1. Implementation of Advisory Agency

\section{Operational activities}

1. Hold data collection on the socio-economic conditions of the community and educational resources in the community

2. Analyze the results of the data collection as an ingredient in providing input, consideration, and or recommendations from the regent and/or the education office

3. Convey input, considerations, and or recommendations in writing to the regent with a copy to the education office

4. Give consideration to the regent and/or head of the education office in the context of developing a local content curriculum

5. Give consideration to the regent and or head of the education office to improve the fun learning and teaching process $(P A I K E M)$

6. Provide input and consideration to the school in the preparation of the vision, mission, goals, policies, programs and activities of Education

\section{Information}

Not yet implemented due to limited operational funds. The Education Board is not supported by regional governments

Not yet implemented, this is related to the form of the first operational activity.

Already carried out during audience activities at the beginning of the management period and submitting work program plans

Already carried out in hearings, communication and coordination with Disdik, including the development of the Cirebon language curriculum and traditional batik crafts. Recommendations regarding this matter were submitted in writing to the Regent.

Already carried out in audience activities, communication and coordination with Disdik, in the form of input the student-centered active learning learning process (by applying PAIKEM teaching) so as not to cause boredom in students. Recommendations regarding this matter were submitted in writing to the Regent.

It has been done, in the form of giving consideration to the school (facilitated by Disdik) in the formulation of vision, mission, goals, policies, programs and educational activities. This activity report is 


\begin{tabular}{|c|c|}
\hline Operational activities & Information \\
\hline & then reported in writing to Disdik \\
\hline $\begin{array}{l}\text { 7. Provide input and consideration to the regent and/or } \\
\text { education office about the implementation of education } \\
\text { management (workforce, finance, facilities, and education } \\
\text { data) }\end{array}$ & $\begin{array}{l}\text { Already carried out in audience activities, communication and } \\
\text { coordination with Disdik, in the form of giving consideration in } \\
\text { rotation and transfer of school principals and teachers, providing } \\
\text { input on educational facilities that need to be upgraded, as well as } \\
\text { providing needed facilities (this identification is based on observations } \\
\text { when conducting monitoring and evaluation). }\end{array}$ \\
\hline
\end{tabular}

\section{Supporting Agency}

\section{Function:}

1) Encourage the growth of attention and community commitment to the implementation of quality education.

Table 2. Implementation of Supporting Agency

\section{Operational activities}

Information

1) Hold meetings or meetings regularly and Meetings have been held, but not regularly. incidentally with existing education stakeholders

2) Encouraging the participation of the community and Not yet done, only limited to establishing communication and business field (DUDI) to support the exploration for cooperation. From this information is obtained implementation of quality education that DUDI participation is only in the closest circle of the company.

3) Motivating the upper middleclass community to increase its commitment to efforts to improve the quality of education in schools

Not yet done on a scheduled basis, it only motivates in general when invited to attend a parent meeting. Motivation is universal, a moral message is inserted to inspire parents to provide optimal support for school programs.

2). Encourage parents and the community to participate in education.

Table 3. Implementation of Supporting Agency

\section{Operational activities}

1) Encouraging the participation of the community and business field (DUDI) in the provision of facilities and infrastructure as well as the cost of education for the poor

2) Participate in motivating the community and all education stakeholders to implement education policies

\section{Controlling Agency}

\section{Function:}

Evaluate and supervise Education policies, programs, implementation and outputs.

Table 4. Implementation of Controlling Agency

\section{Operational activities}

1) Hold coordination meetings with school committees

2) Hold visits or hospitality to the school

3) Request an explanation of the education office about student learning outcomes

4) Cooperate with the education office to conduct an evaluation of the implementation of education policies
1) Hold coordination meetings with school committees

\section{Information}

Not yet implemented, due to budget constraints and human resources.

It has been done, but not routinely through electronic media (TV/Radio) through talk shows.

\section{Information}

It's been done, it's not routine and hasn't touched the whole school. For the elementary level, coordination is carried out through the School Committee forum. For junior and senior high school, the Education Board receives an invitation to the parents' meeting.

It has been done even though it is not routine (conducted at the time of the monitoring and evaluation scheduled by Disdik).

Not yet done, the education council entrusted the evaluation of learning outcomes to Disdik.

It has been carried out in the form of involvement in monitoring and evaluation activities and providing recommendations on the rotation of the transfer of teachers and principals. 


\section{Mediator}

\section{Function:}

1) Cooperate with the government (individual/organization) of the government and the DPRD regarding the implementation of quality education.

Table 5. Implementation of Mediator

\begin{tabular}{ll}
\hline \multicolumn{1}{c}{ Operational activities } & \multicolumn{1}{c}{ Information } \\
\hline 1) Fostering relationships and harmonious cooperation & Not yet done, because of budget constraints and human \\
with all education stakeholders, especially with & resources \\
$D U D I$ in the area &
\end{tabular}

2) Accommodate and analyze the aspirations, ideas, demands and various educational needs proposed by the community

Table 6. Implementation of Mediator

\section{Operational activities}

1) Distributing questionnaires to obtain input, suggestions, and creative ideas from education stakeholders

2) Submit a report to the public in writing, about the results of his observations on the development of education

Overall the Board of Education has carried out its role and function, although it is still not optimal. That is, despite the various limitations that exist, the Board of Education has sought to perform its role and function. This is in line with research conducted by Iwan Panji which states that the overall role of the Yogyakarta City Education Board has been considered good by the majority of the public with a percentage of categories of $62.7 \%$. In the very good category as much as $21.6 \%$, while in the quite category as much as $13.1 \%$. But there are still $2.4 \%$ with the category of not good and $0.2 \%$ with the category of not very good (Iwan Panji, 2018). The non-optimal implementation of the role and function of the Board of Education is also due to the unpopularity of this Institute among the public. Research conducted by Hendarman in several Education Councils both at the Provincial and Regency/City levels states that "From the above findings it can be said that the education council has performed a role related to improving the quality of education services at different levels starting from those at the assessment level. to the level that has made the council the main partner of the regional government. In addition, there are a variety of approaches used by the education council in carrying out its role to improve the quality of education services in each region. Several boards at the provincial/district/city level have upheld the principles of transparency, accountability and democracy. However, these principles do not appear to be fully implemented in other districts/cities in Indonesia. The implementation of these principles has not been highly correlated with a variety of policies and political dynamics that have developed in each district/city. It is suspected that this is one of the causes of not being known or having the same perception from the local community regarding the existence and role of the education council in the process of improving the quality of Education services (Hendarman, 2012).

\section{Product stage}

Evaluation on the results of the long term outcomes in the implementation of the Policy on the Education Board in Cirebon Regency was carried out on 3 aspects which were the objectives of the formation of the Education Board, namely: (1) accommodating and channeling $\mathrm{n}$ community aspirations; (2) the responsibility and active participation of the community in the implementation of education; and (3) creating a transparent, accountable and democratic atmosphere in the implementation of education. The evaluation results show that overall the formation of the Education Board in Cirebon district has not provided optimal results. Only a part of its roles and functions have been carried out, namely the advisory agency as described in the process stage. The implementation of the role and function of the Education Board is very much dependent on the budget and quality human resources. The absence of a budget has resulted in the non-optimal implementation of work programs arranged in order to carry out roles and functions. Similarly, the quality of human resources is less qualified.

It is understandable that development is a continuous process that covers all aspects of people's lives. In the 
development process, the role of education is very strategic. If the quality of public education is high, it is expected that the people's mindset will also be better, which in turn will be able to increase their income. Thus, it can be said that public education is one of the determinants of the condition of the HDI (Human Development Index) which represents the level of welfare of the people in a region. Cirebon Regency HDI Education based on data in 2015 was 76.86 with an average length of school (RLS) of 7.01 and literacy rates 94.07 (BAPPEDA Kab. Cirebon, 2017). The variables used in calculating the Educational HDI are: (a) Average length of school; and (b) Literacy Numbers. In the meantime, the school's old expectation rate is 11.79 years. From these data it can be concluded that the hopes of the Cirebon District people can at least graduate from high school, while in reality the average community has just graduated from elementary school and dropped out in first grade of junior high school (seen from the average length of school 7.01). These figures indicate that the government's 9-year basic education program is not yet complete. Besides that, Cirebon Regency still leaves a range of 87 thousand people aged 15 years and over who are still not literate. Even though reading ability (literacy) is a basic ability to absorb knowledge and skills. From this it seems clear that the educational attainment in Cirebon Regency is still far from the current national education target, which is reasonable in 12 years. Of course, this has become quite a chore for the local government of Cirebon Regency and all components of the community to be able to improve educational achievement.

In connection with the need for community participation in education, School Committees in each education unit should be optimized for their roles and functions. School committees are expected to partner with schools to develop the quality of education by using the concept of School Based Management and a democratic, transparent and accountable society. Efforts to optimize the participation of the community can be realized through socialization, fostering School Committees, community care forums, and other activities that can broaden insights and understanding of the role of the community and the School Committee in the management of education. This socialization and coaching activity will be carried out well if the role of the Education Council which is a forum for community participation at the district level is also optimized. Through this Board of Education, School Committees at each level of education are invited to communicate, share about the difficulties faced in their educational units, then work out solutions to their solutions. Of course, by involving advice and input from education observers and the business field (DUDI) in Cirebon.

In addition, through the School Committee can also be carried out coaching/socialization as an effort to increase public awareness of the importance of education. This is an important thing to do, because there are 18 sub-districts that have an average number of school years below 6 years (BAPPEDA Cirebon Regency, 2017). This means that in the sub-district, the community has not finished elementary school. Greged is one of Subdistrict with the lowest $R L S$. The $R L S$ is 3.95 which means that the population in this region is only schools up to grade ${ }^{3 \text { th }}$ of elementary school or drop out in grade ${ }^{\text {th }}$ (BAPPEDA Cirebon Regency, 2017). Indeed, this has a positive correlation with the level of poverty. Waled is the most populated area of the "very poor" category Subdistrict, which is as many as 18,196 people or $15.18 \% \quad$ (BAPPEDA Cirebon Regency, 2017). Of course, this has resulted in low purchasing power, which in turn has resulted in a low level of education due to their low awareness of the benefits of education. For this reason, through synergy with the Education Board, School Committees, and the Education Office (as responsible for education in Cirebon District), socialization will be carried out as an effort to build public awareness of the importance of education.

In fact, the Education Board as a forum for channeling people's aspirations, has not been able to function optimally. The existence of the Education Board has not been understood by the community at large, including community leaders who care about education. The aspirations of community leaders are generally conveyed to village officials or schools directly. The lack of communication between the Education Board and the School Committee also made this institution unable to become a forum for people's aspirations properly. Likewise, in terms of building community motivation and concern for education. The Education Board should be able to motivate the community through the School Committee. However, due to the lack of optimal communication and coordination with the Committee, public awareness cannot be motivated properly.

Similarly, efforts to increase the responsibility and active participation of the community in the implementation of education in Cirebon Regency. The Education Board has not been able to optimize this effort. Community participation in education can actually be built through school committees and DUDI. Through committee administrators, parents' awareness can continue to be built so that they can play an active role at least in their respective schools. Minimal formation of school committees will result in low awareness of parents of students to participate in school programs. The Education Board has also not been able to neutralize the negative stigma of the school committee as a school tool for collecting student parents' contributions. Furthermore, the Education Board must also be able to collaborate with $D U D I$ to expand the scope of its contribution to education in Cirebon Regency and actively participate in improving the quality of schools throughout the Cirebon Regency. DUDI as one component that has a great opportunity to contribute to education has not been touched by the Education Council. Therefore, communication and coordination are needed especially with the regional government so that the Education Board is able to optimize DUDI's contribution in improving the quality of 
education.

In connection with the creation of transparency, in the implementation of education some have been realized by the Education Board. monitoring and evaluation in $P P D B, U N / U A S B N, B O S, D A K$, etc. by the Education Board encouraged the creation of transparency. Accountability is also evident from the issuance of reports on the use of funds for donations and fees in schools that are submitted in writing to the school committee and parents of students. However, so far the school has not involved committees in the preparation of school policies and programs, so that this means that democratization has not been realized in the implementation of education. Collaborative awareness between the school and the school committee needs to be built about the need for committee involvement in the preparation of school programs.

\section{CONCLUSION}

Empirically this research proves that the conditions at the design stage and the installation stage are good does not guarantee the success of the implementation of the policy without a good process support. Outcomes or results that are not optimal can be caused by weaknesses at the stage of the policy implementation process. The fact shows that the implementation of the policy on the formation of the Education Board in Cirebon Regency has been supported by design and installation of policies including the guidelines, mechanisms and planning of good work programs. However, in the process of implementation, adequate financial and resource support is not yet available, so that the expected goals cannot be achieved optimally. As a result, the results achieved have not met the desired expectations.

Being a member of the Education Board is a social work, as described in their $A D / A R T$, that the Education Board is a non-profit institution. Therefore, the work values of the Education Board must be lived as social work and not as a place of self-actualization, feeling a more prestigious social position as a members of the Education Board, but not optimal in completing their duties. Some members of Education Board in Cirebon Regency are retirees who are considered concerned by education issues. However, this results in less optimal performance, due to various limitations (time, effort, administrative competence, etc.). Offices and facilities in accordance with the minimum administrative facilities standard for work are indeed available at the Cirebon District Education Board office. However, the unavailability of financial support is the biggest inhibiting factor for the implementation of the activity program plan. The limitations of the entrepreneurship Education Board also hampered fundraising efforts independently to finance work programs that had been prepared. In addition, a high verbal culture but does not do administration well, makes the Education Board less than optimal because they cannot conduct performance evaluations. In other words, the competence of the
Education Council in the field of administration is low, so it cannot conduct performance evaluations because there is no data.

Support from related institutions, especially the Education Office, is also a crucial factor for the optimal functioning of the Education Board. The position of the Education Board is as a partner for the Education Office to carry out the development of the education sector in Cirebon Regency. Therefore, synergy, communication and coordination as well as delegation of authority to several activities that can be carried out together with the Education Board must be optimized. Thus, the Education Board program can be implemented through budget allocations from the Education Office in agreed programs.

\section{Acknowledgements}

The researcher would like to thank The Ministry of Research Education of Republic Indonesia for providing fund in financing the University fees through scholarship.

\section{REFFERENCE}

Aref, A. (2019). Community Participation for Educational Planning and Development.

BAPPEDA Cirebon Regency. Socio-Cultural Profile of Cirebon Regency in (2017). Cirebon.

Caldwell, B. J. (2005). School-based management International Institute for Educational Planning. Paris, perancis: The International Institute for Educational Planning (IIEP). Retrieved

from http://www.iaoed.org/downloads/Edpol3.pdf

Cheng, Y. C. (1996). School Effectiveness and School-based Management: A Mechanism for Developmen. London, Washington DC: The Falmer Press.

Coles, J. L., Daniel, N. D., \& Naveen, L. (2012). Board Advising. SSRN Electronic Journal.

https://doi.org/10.2139/ssrn.2002250

Ministry of Education. Reference operational activities and school committee performance indicators (2003). Ministry Directorate General Of Basic And Medium Education, Educational Board Development Team And School Committees, 2003

Depdiknas. Kepmendiknas No 044/U/2002 About the Board of Education and School Committee (2002).

Ehren, M. C. M., Honingh, M. E., Hooge, E. H., \& O’Hara, J. (2013). Changing school board governance in primary education through school inspections. Educational Management Administration and Leadership, 44(2), 205-223. https://doi.org/10.1177/1741143214549969

Hendarman. (2012). The Role of Education Board in Improving The Quality of Service for Education, 18, 34-44. Retrieved from

http://jurnaldikbud.kemdikbud.go.id/index.php/jpnk/art icle/view/67

Hooge, E., \& Honingh, M. (2014). Are School Boards aware 
of the educational quality of their schools? Educational Management Administration and Leadership, 42(3), 139-154. https://doi.org/10.1177/1741143213510509

Iwan Panji, W. (2018). Public Perception of The Role of The Education Board of Yogyakarta City, 5(7), 10-18. Retrieved from https://eprints.uny.ac.id/41713/

Johnson, P. A. (2012). School Board Governance. Journal of Cases in Educational Leadership, 15(2), 83-102. https://doi.org/10.1177/1555458911413887

Evaluation Study on the Impact of the Education Board / School Committee's Contribution to the Improvement of Secondary Education Quality. (2011). Retrieved from http://staff.uny.ac.id/sites/default/files/penelitian/aprinu ryantospdstmt/laporan-kajian-evaluasi-dampak-1.pdf

Decree of the Minister of National Education of the Republic of Indonesia Number 129a/U/2004 concerning Minimum Service Standards in the Field of Education (2004). Retrieved from

http://luk.staff.ugm.ac.id/atur/bsnp/Kepmendiknas129a -U-2004 Minimum Service Standards.pdf

Kompas.com. (2012). School Committees Utilized to Withdraw Wild Levies, Kompas.com.

Government Agency Performance Accountability Report (LAKIP) Cirebon District Education Office. (2018). Cirebon.

Mas, S. R. (2011). Community and Parent Participation in Education Organization. El-Hikmah, VIII(2), 184-196. Retrieved from http://ejournal.uin-malang.ac.id/index.php/elhikmah/art icle/view/2243/pdf

Muhtadi, A. (2008). Comparative Study of Education Systems in Germany and South Korea. Yogyakarta State University.

Pailwar, V. K., Mahajan, V., \& Africa, S. (2005). Janshala in Jharkhand: An experiment with community involvement in education, 6(3), 373-385.

Pardji. (2011). Meaning of the implementation of education and school committee. Jurnal Ilmu Pendidikan, 17(6), 469-475. Retrieved from

https://www.researchgate.net/publication/307798614_D efinition of_Education_and_School Committees

Cirebon District Government. Regional Regulations of Cirebon Regency No. 13 Tahun 2011 regarding the Implementation of Education (2011).

Government of the Republic of Indonesia. Government Regulation Number 17 of 2010 concerning Management and Implementation of Education (2010).

Pikiran Rakyat. (2015). The Education Board and School Committee Should Be Disbanded, Pikiran Rakyat online.

Education Blur Portrait of Cirebon Regency,Cirebon News online. (2016). Cirebon News Online.

Provus, M. M. (1969). The Discrepancy Evaluation Model An Approach to Local Program Improvement and
Development. (B. J. McCormick, Ed.). USA: Pittsburgh Public Schools. Retrieved from

https://eric.ed.gov/?id=ED030957

Santoso, Y., \& Zulaikha, S. (2017). Autonomy And Community Participation On The Implementation Of School- Based Management In The City Of South Tangerang, 118, 1126-1131.

Suru, A. S. (2013). Community Participation in Improving the Quality of Education. Jurnal Eksekutif, (Vol 1, No 1 (2013)). Retrieved from

http://ejournal.unsrat.ac.id/index.php/jurnaleksekutif/a rticle/view/2463

Suryono, A., Santosa, R., \& Haryadi. (2013). Implementation of Government Regulation Number 66 of 2010 on Empowerment of the Education Board and School Committees. Jurnal Dinamika Hukum, 13(2).

National Education System Law (2003). https://doi.org/10.16309/j.cnki.issn.1007-1776.2003.03.0 04

Wiratno, B. (2016). Community Participation in Education, 26(1), 28-34. Retrieved from

http://journals.ums.ac.id/index.php/jpis/article/view/206 $2 / 1564$

Yau, H. K., \& Cheng, A. L. F. (2011). Principals and Teachers' perceptions of School policy as a key element of School-Based Management in Hong Kong Primary Schools. Spring, 9(1). Retrieved from

http://www.leadingtoday.org/weleadinlearning/Spring2 011/Article 9 - V9N1 - Yau and Cheng.pdf 